\title{
Magnetic Field Application: An Underappreciated Outstanding Technology
}

\author{
Djamel Ghernaout ${ }^{1,2 *}$, Noureddine Elboughdiri ${ }^{1,3}$ \\ ${ }^{1}$ Chemical Engineering Department, College of Engineering, University of Ha'il, Ha'il, KSA \\ ${ }^{2}$ Chemical Engineering Department, Faculty of Engineering, University of Blida, Blida, Algeria \\ ${ }^{3}$ Département de Génie Chimique de Procédés, Laboratoire Modélisation, Analyse, et Commande des systèmes, Ecole Nationale \\ d'Ingénieurs de Gabès (ENIG), Rue Omar Ibn-Elkhattab, Gabès, Tunisia \\ Email: ${ }^{\star d j a m e l \_a n d a l u s @ h o t m a i l . c o m ~}$
}

How to cite this paper: Ghernaout, D. and Elboughdiri, N. (2020) Magnetic Field Application: An Underappreciated Outstanding Technology. Open Access Library Journal, 7: e6000.

https://doi.org/10.4236/oalib.1106000

Received: December 13, 2019

Accepted: January 4, 2020

Published: January 7, 2020

Copyright $\odot 2020$ by author(s) and Open Access Library Inc.

This work is licensed under the Creative Commons Attribution International License (CC BY 4.0).

http://creativecommons.org/licenses/by/4.0/

\section{(c) (i) Open Access}

\begin{abstract}
In diverse machines, as much as $90 \%$ of all particles suspended in the oil can be iron or steel and can be particularly troublesome to operators. This article looks at magnetic filtration advantages and benefits; moreover, it focuses on how this physical technology can often outperform traditional methods. Magnetic filtration is a process in which two objects are separated; one of them has to be metallic, to be attracted by means of magnets. Magnetic systems ideal for the food industry, as they protect the final product and the machinery used in its production process. Another important magnetic field application is in the water treatment technology. Despite the great achievements in the application of the magnetic field through the above-mentioned domains, more efforts should be performed to promote this green technology implementation in the industries in terms of practical usage. More attention has to be accorded by researchers to better familiarize industrials with this hugely promising technique.
\end{abstract}

\section{Subject Areas}

Civil Engineering

\section{Keywords}

Magnetic Field (MF), Magnetic Filtration, Iron, Separation, Magnetic Water Treatment, Green Technology

\section{Introduction}

Since industrial filtration techniques persist to progress, occasionally selecting one may be a many-sided resolution. There are a set of parameters, which inter- 
fere when deciding the most performant technique. In many situations, the integration of techniques is really the most convenient choice. One that appears to be an underused technique in the industry is magnetic filtration [1] [2].

Most processes not presently employing a type of magnetic filtration in its running may hugely profit via applying it. Equipment operators, maintenance technicians and reliability engineers all are aware and comprehend the significance of clean oil in attaining machine accuracy. Further, most experimented oil analysts come to an agreement that in numerous machines, as much as $90 \%$ of all solids suspended in the oil may be iron [3] or steel. These sorts of particles may be very disturbing [1] [4].

Typically, one or both of any lubricated, sliding, or rolling surfaces will have iron or steel metallurgy. These may comprise any number of frictional surfaces employed in gearing, rolling-element bearings, piston/cylinders, etc. [1] [5].

\section{Magnetic Strength}

Through forming a magnetic field (MF) or loading zones that gather magnetic iron [6] [7] and steel particles, magnetic filters may usually exceed conventional, mechanical filters (Figure 1). With magnetic filtration technique, magnets are geometrically placed to induce an MF that has a non-uniform magnetic strength [1].

This technique is usually utilized with rotating drums employed for tool coolants with elevated degrees of machining waste. Moreover, filter housings may be employed with a full collection of magnets and no filter media, with an aim to only capture ferrous metals. In the end, there is a flow among magnetic filters in the application. These are filter housings where there is no filter element. Alternatively, the magnets are in plates fixed through a rod that plays the role of a classical filter element [1].

However, cannot mechanical filters eliminate particles that are almost the same size? Whereas it is correct that traditional mechanical filters may eliminate

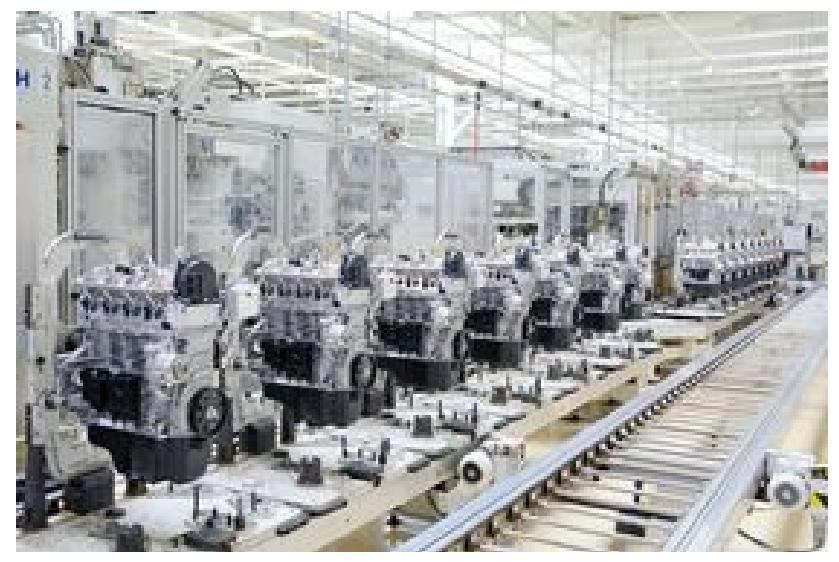

Figure 1. Magnetic filters are frequently employed throughout the industrialization step in the automotive industry. Via generating an MF or loading zones that gather magnetic iron and steel particles, magnetic filters may usually surpass classical, mechanical filters [1]. 
solids in the same size range as magnetic filters, most of these filters are disposable and incur a cost for each gram of particles retained [1].

Furthermore, employing magnetic filters over particulate filtration will need lower power consumption. This is attributed to the flow limitation provoked by the fine pore-size filter media. As pores become plugged with solids, the limitation augments proportionally, pushing the power required to run the filter system efficaciously to rise [1].

\section{Conditions}

The resolution to apply the magnetic technique in a specified purpose has constantly to be affected by diverse machine circumstances and fluid cleanliness targets. As an illustration, what is the anticipated concentration of ferrous particles? What sort of oil is employed? What is the running temperature, surge flow, shock, and machine design? [1] [8]

Since there are many commercial products, arrangements and usages, some benefits and drawbacks debated in this work may not apply. Nevertheless, comprehending the diverse parameters may function as a major starting point for making the resolution of if the magnetic technique is an appropriate solution in a specific usage [1] [9] [10].

\section{Benefits}

More important, magnetic filtration is viewed as a reusable technique. This evidently significates that it is a more cost-efficient technique than a conventional mechanical filter. The price of retaining a gram of solids from the oil using a magnetic technique is a portion of that afforded when only employing disposable filters. Thus, from an apple-to-apple rapprochement, employing magnetic filtration as compared to the usual disposable technique will, in the end, be friendlier to the bottom line [1] [11].

Moreover, there is the problem of flow limitation as the filtration is in utilization (Figure 2) [12]. Different from traditional filters, most magnetic filters do not manifest an elevation in flow limitation since they load with solids. This may be greatly beneficial. While classical filters may go into bypass at what time they begin to be plugged with solids, magnetic filters persist to eliminate solids and let oil flow [1] [9] [13].

\section{Augmented Performance}

One of the largest benefits of magnetic filtration is that it does not consistently have to be an "either/or" case. Indeed, if employed in simultaneity with traditional mechanical filters, magnetic filtration can conduct to an elevation in the mechanical filter's efficient service life. The effect may be so huge that in some situations, two or three times as much may augment a mechanical filter's life. A popular instance of this is employing a magnetic insert on a bag filter housing [1] [10]. 

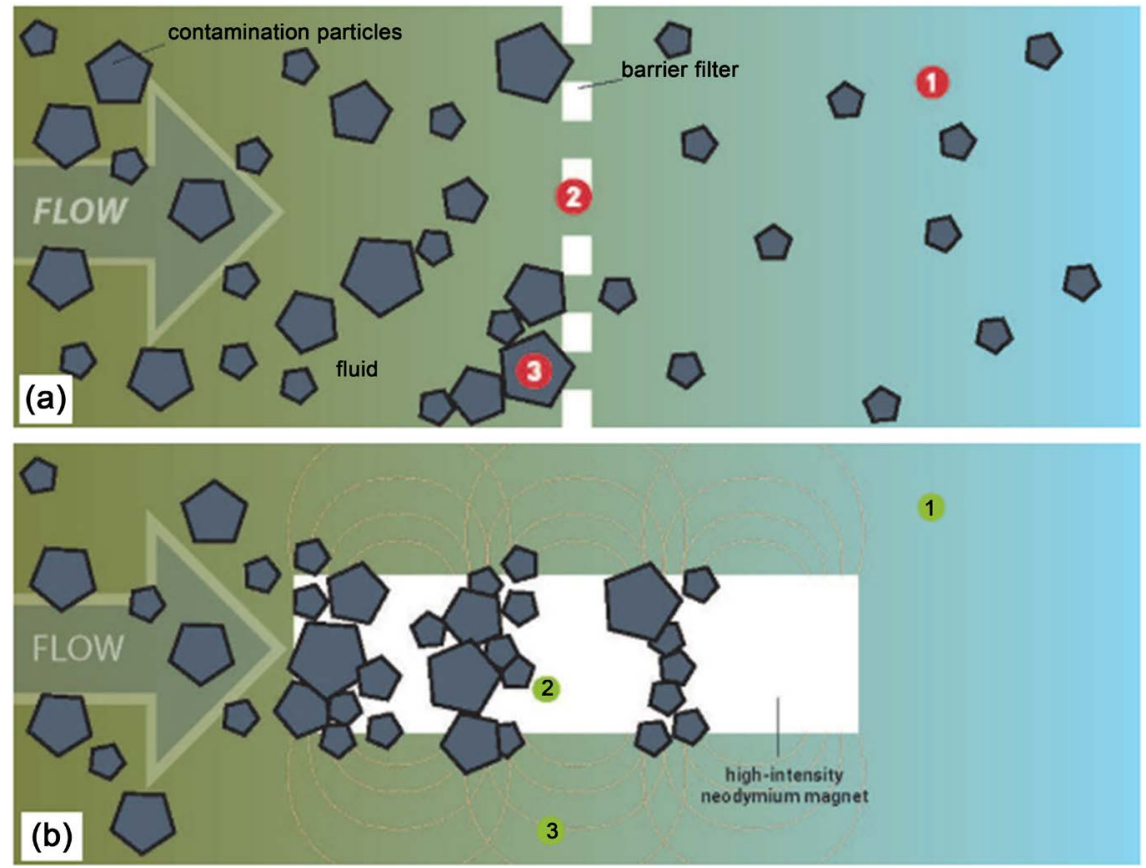

Figure 2. (a) Barrier filtration ((1). Particles smaller than the pore size remain in the fluid, reducing its efficiency and increasing wear on machinery and cutting tools. (2). Once full, the contaminated media is disposed of (along with fluid held in it). (3). The filter can become clogged causing blinding and back pressure), and (b) magnetic filtration ((1). High intensity magnets remove all particles and clean fluid continues uninterrupted on its way. (2). Once full, the contamination is removed from the magnet and can be recycled with minimal fluid loss. (3). Patented magnetic design means that the filter will not block so there is no blinding or pressure build up) [12].

The following main advantage of employing magnetic filtration is how it saves the equipment that the liquid is running through. More important, servo and solenoid valves may be excessively deteriorated by solids that are magnetic (like iron and steel). Through constantly eliminating such solids using magnetic filters, the accuracy of such valves may be basically ameliorated [1].

Moreover, magnetic filtration will better keep against early oil oxidation, which may conduct to varnish, sludge, and corrosion. Everything else being equal, the persistent elimination of iron and steel particles via magnetic filters has to possess a favorable influence on oil service life [1].

\section{Magnetic Filtration}

Both the set of magnets employed and manners in which magnetic filters and separators may be installed in a product's design are both crucial parameters that touch magnetic filtration. There is much more to their efficiency than just the strength or gradient of the MF. For instance, the size and design of the flow chamber, the total surface area of the magnetic loading zones, and the flow path and contact period of the oil are all substantial design parameters. These parameters affect the yield of separation, the size of solids being retained, and the global capacity of solids hold by the separator [1]. 
The magnetic force acting on a solid is proportional to the volume of the solid. Nevertheless, it is also disproportional to the diameter of the solid. For example, a two-micron solid is eight times more attracted to a MF than to a one-micron particle. Due to this, big ferromagnetic particles are easier to retain from a fluid than smaller ones. The separating force is proportional to the MF gradient and the particle magnetization (the degree to which the particle's material composition is affected by a MF) [1].

Solids made of iron and steel are the most powerfully attracted materials. Nevertheless, red iron oxide (rust) and high-alloy steel (for instance, stainless steel) are just weakly attracted to MFs. On the contrary, several nonferrous compounds like nickel, cobalt, and certain ceramics are known to possess a powerful magnetic attraction. Materials that cannot be picked up with a magnet, such as aluminum are named paramagnetic substances [1].

\section{Competing Forces}

It is crucial to remember that there are competing forces that counter particle separation from the fluid. Oil velocity is one such example, which imparts inertia and viscous drag on the particle in the direction of the fluid flow. Relying on the design of the magnetic filter, the fluid velocity may send the particle on a trajectory toward or away from the MF. This competing viscous force is proportional to both the particle's diameter and the oil viscosity. If the particle's diameter or the oil's viscosity augments, the hydrodynamic frictional drag will augment proportionally [1].

The magnetic attraction augments by a factor of eight when a particle's diameter doubles, while the competing viscous drag sees only a two X multiple. This is significant to pay attention and then establishes how big particles are more facilely separated than small particles, even in an environment of considerable viscous drag [1].

Particle capture performance by magnetic technique may be classified into three factors listed in Table 1 [1].

Most filtration operations will have some usage for magnetic filtration. If there are metal particles being filtered out in any way, it is usually a profitable

Table 1. Three factors determining particle capture efficiency [1].

\begin{tabular}{ll}
\hline \multicolumn{1}{c}{ Factor } & \multicolumn{1}{c}{ Description } \\
\hline Factor \#1: Particle properties & $\begin{array}{l}\text { The larger the particle, the easier it should be to separate. Further, if } \\
\text { it consists of a highly magnetic material (for instance, iron and } \\
\text { low-alloy steel), it will be subject to great capture efficiency. }\end{array}$ \\
Factor \#2: Fluid features & $\begin{array}{l}\text { The fluid conditions that best facilitate the separation of magnetic } \\
\text { particles are low oil viscosity and low oil flow rate. If these } \\
\text { conditions are met, extremely small, one-micron particles can be } \\
\text { separated from the oil efficiently. } \\
\text { Factor \#3: Magnet design }\end{array}$ \\
& $\begin{array}{l}\text { Magnetic filters that use high-flux magnets and are installed in a } \\
\text { fashion that grows high-gradient magnetic will be the most efficient. }\end{array}$
\end{tabular}


technique. Whether substituting conventional filters or improving their performance, magnetic filtration may be extremely useful [1].

\section{Magnetic Water Treatment}

Comprehension of the MF impacts noted through and following its exertion on water and aqueous solutions remains a polemic question even if the influences have been published for several decades [14] [15] [16] [17] [18]. Chibowski and Szcześ [19] discussed the literature which concerns the magnetic force treatment influences. As a rule, the modifications in water construction by hydrogen bonding alterations, as well as in intraclusters and among interclusters were considered. However, the most notable development was attained seven years ago by Coey [20] who used the non-classical theory of nucleation mechanism of the generation of dynamically ordered liquid-like oxyanion polymers (DOLLOP) to interpret the MF contribution (Figure 3). His criterion for the MF impact to take place was experimentally confirmed (Table 2). It was as well demonstrated that the gradient of the MF is more significant than the MF strength itself [21]. Numerous useful procedures interpreting an improved evaporation yield of water through an MF are also reviewed.

Han et al. [53] exposed water (Figure 4) and $\mathrm{KCl}$ solutions to four diverse MFs for $20 \mathrm{~min}$, respectively. They investigated the impacts of the MF on microscopic structures and macroscopic features of water and $\mathrm{KCl}$ solutions using FTIR and the continuous spectrum techniques of linearly polarized light in ultraviolet, visible and near-infrared areas (Figure 5). They observed that in the UV-vis area, the transmittance of all samples exhibited diverse phenomena when the incident light with different polarized, it resulted from the orientation of water molecules affected by the static MF and the spiral motion of ions in the MF. The IR spectrum showed that $\mathrm{KCl}$ had a significant structure-breaking effect when the intensity of the MF increased and the absorption in the spectrum of $\mathrm{KCl}$ was a reflection of the perturbations that water bore in the presence of $\mathrm{K}^{+}$ and $\mathrm{Cl}^{-}$ions.

In the last years, numerous investigations on the influences of the MF on the water (Figure 6) have been published; however, still, several arguments and

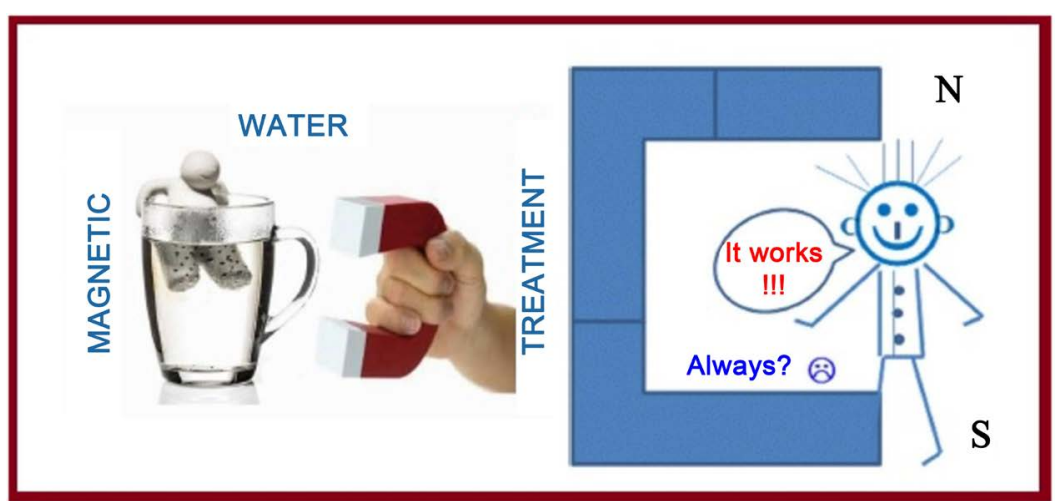

Figure 3. Magnetic water treatment [19]. 
Table 2. Published impacts due to MF treatment [19].

\begin{tabular}{|c|c|c|}
\hline No & Phenomenon or parameter & MF effects and comments \\
\hline 1 & Nucleation & Reduces the induction period, augments its rate. Slower nucleation of $\mathrm{CaCO}_{3}$, altered crystalline structure. \\
\hline 2 & Proton transfer & Faster transfer from $\mathrm{HCO}_{3}^{-}$to water. Larger number of nuclei is formed. \\
\hline 3 & Crystal forms & Influences $\mathrm{CaCO}_{3}$ structure. More aragonite than calcite precipitates [22]. \\
\hline 4 & Particle size & Smaller particles. More stable dispersions [23] [24] [25]. \\
\hline 5 & Entropy of hydration [26] & MF effect depends on the entropy. Proportional to the entropy of ion hydration. \\
\hline 6 & Zeta potential & $\begin{array}{l}\text { Changes zeta potential of the precipitate due to ions adsorption [27] [28] [29]. It may reverse its sign [30] } \\
\text { [31] [32]. }\end{array}$ \\
\hline 7 & Cluster transformation & Intercluster and intracluster transformation occur. \\
\hline 8 & Hydogen bonds & $\begin{array}{l}\text { Weakens the water intercluster bonds and strengthens the intraclusters bonds. Slight increase in the amount } \\
\text { of the bondings. }\end{array}$ \\
\hline 9 & Lorentz force & $\begin{array}{l}\text { Affects the ion clusters, increase their mobility, weakens the solute/solvent interactions. The number of } \\
\text { contacts of ion pairs increases and the amount of water pairs decreases. }\end{array}$ \\
\hline 10 & Mobility of ions & $\begin{array}{l}\text { Increases mobility, e.g. } \mathrm{Na}^{+} \text {and } \mathrm{Cl}^{-} \text {. Diffusion mobility of cations increases and anion decreases [33] [34] } \\
\text { [35]. (Simulated results). }\end{array}$ \\
\hline 11 & Ion polarization & $\begin{array}{l}\text { Especially bivalent ions [36] [37] [38]. More of cations because they are strongly hydrated than anions [38] } \\
\text { [39] [40]. }\end{array}$ \\
\hline 12 & Surface tension & Increases or decreases surface tension [41] [42] [43]. (Contradictory results). \\
\hline 13 & Viscosity & Increases viscosity. A larger increase at a higher temperature. (Contradictory results). \\
\hline 14 & Memory effect [44] & The changes in physical properties may last up to 2 days. \\
\hline 15 & $\begin{array}{l}\text { Electrical double layer [45] } \\
\qquad[46][47]\end{array}$ & $\begin{array}{l}\text { Shift of ions from the Gouy-Chapman diffuse part toward Stern compact part [48]. Charge neutralization } \\
\text { [49] of the dispersed phase and sedimentation [50] [51] [52]. }\end{array}$ \\
\hline 16 & Evaporation rate & $\begin{array}{l}\text { The rate can increase. Depending on the field direction, the Lorentz force may orient water dipole and thus } \\
\text { enhanced evaporation. }\end{array}$ \\
\hline
\end{tabular}

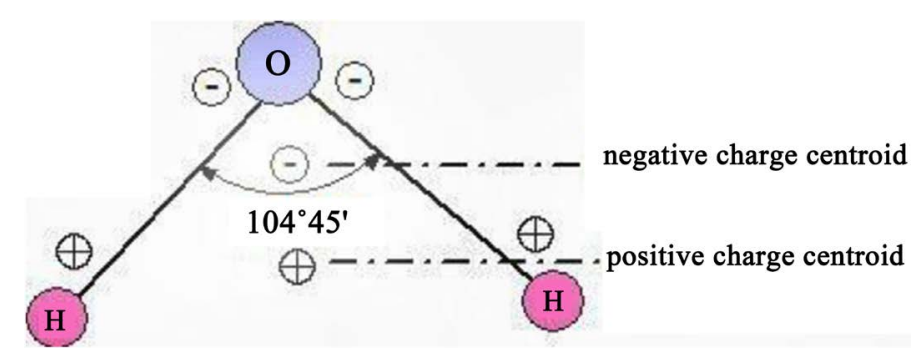

Figure 4. Model of individual water molecule [53].

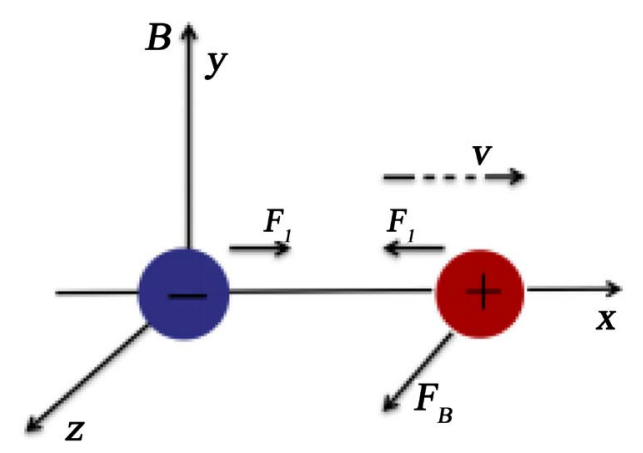

Figure 5. Diagram for electric dipole under the action of static MF [53]. 


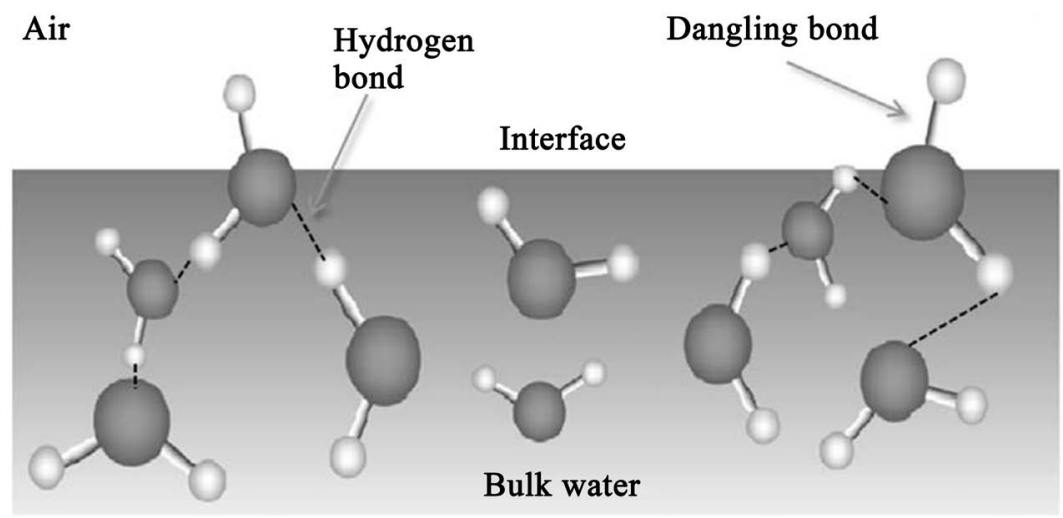

Figure 6. Water-air interface structure with dangling bond of hydrogen atoms in air above interface. Big and small spheres represent Oxygen and Hydrogen atoms, respectively [44].

doubts exist. Nevertheless, the augmentation in water evaporation because the existence of the MF is less in conflict. Seyfi et al. [44] examined the impacts of static MF on the quantity of deionized water evaporation in the existence of an MF with one, two or three permanent ferrite magnets perpendicular to the water-air interface. They demonstrated that the tangential MF at the interface does not alter the quantity of evaporation; however, when the MF is perpendicular to the interface, up to $18.3 \%$ elevation in water evaporation percentage is detected. An additional remarkable impact of the MF remains the memory effect, which appears when the MF is applied perpendicular to the interface with three magnets for $60 \mathrm{~min}$ after eliminating the magnets even up to $40 \mathrm{~min}$ more evaporation compared to non-magnetic water is still perceivable. These influences are interpreted and debated employing the kinetic energy of water molecules and Lorentz force on these moving charged molecules at the interface, which provokes weakening or breaking hydrogen bonds.

Lipus et al. [54] discussed electromagnetic water treatment, as an option solution for scale control in industrial water processing and tested a model setup with solenoid coils inserted into a cylindrical kernel inside a pipe for possible implementation at high water-flow capacity (few hundreds of $\mathrm{m}^{3} / \mathrm{h}$ ). A powerful $\mathrm{MF}$ (e.g. with maximum magnetic flux density from $0.1 \mathrm{~T}$ to $0.2 \mathrm{~T}$ ) may be generated employing a DC electric supply resulting in total costs at least ten times lower than the expense of the scale-prevention ion exchange.

\section{Conclusions}

The main points drawn from this work may be given as:

1) Chibowski and Szcześ [19] reviewed the literature focusing on the magnetic treatment of water, mostly in the aspect of hard scale prevention, and concluded that there remains a lack of consistent theory of the field mechanism work. Nevertheless, the researches known through the last years obviously put forward our understanding of the field action which is based on changes in the structure of water via hydrogen bonding in intraclusters and between interclusters. 
2) The contribution of the Lorentz force if acting perpendicularly to the water/ air interface in the water evaporation rate was presented lately. Because a potential gradient exists at the interface and the gas phase susceptibility changes, the force enhances water evaporation. It is believed that new results of further studies applying the DOLLOP approach will be published soon thus developing our understanding of so far, not well-understood processes [19].

3) The FTIR and UV-vis-near IR spectrums depicted that the MF modifies the distribution of molecules and electrons, induces displacements and polarization of molecules and atoms, and conducts to changes of dipole-moment transition and vibrational states of molecules and variation of transition probability of electrons; however, it does not alter the constitution of molecules and atoms. Otherwise, $\mathrm{KCl}$ has a crucial structure-making impact. These findings are useful in investigating the pathway of magnetizing water and solutions [53].

\section{Conflicts of Interest}

The authors declare no conflicts of interest regarding the publication of this paper.

\section{References}

[1] FILTSEP (2019) Magnetic Filtration-Are You Using It? https://www.filtsep.com/filter\%20media/features/magnetic-filtration-are-you-using -it

[2] Imamagnets, Magnetic Filtration. https://www.imamagnets.com/en/magnetic-filtration/

[3] Ghernaout, D. and Elboughdiri, N. (2019) Iron Electrocoagulation Process for Disinfecting Water-A Review. Applied Engineering, 3, 154-158.

[4] Magnetic Filter (2017) https://www.youtube.com/watch?v=Zm7I0PpQE4Y

[5] Fitch, B. (2019) Magnetic Filtration Applications and Benefits. https://www.machinerylubrication.com/Read/794/magnetic-filtration

[6] Ghernaout, D. and Elboughdiri, N. (2019) Mechanistic Insight into Disinfection Using Ferrate(VI). Open Access Library Journal, 6, e5946.

[7] Ghernaout, D. and Elboughdiri, N. (2019) Water Disinfection: Ferrate(VI) as the Greenest Chemical-A Review. Applied Engineering, 3, 171-180.

[8] Magnetic Filters (2019)

https://www.goudsmitmagnets.com/industrial-magnetic-systems/magnetic-filtering /magnetic-filters

[9] Fowler, N. (2012) The Attraction of Magnetic Filtration. https://www.americanmachinist.com/shop-operations/article/21897576/the-attracti on-of-magnetic-filtration

[10] Benefits of Magnetic Filtration (2019) https://www.dseslc.com/blog/benefits-of-magnetic-filtration/

[11] Commercial Filtration Supply, What Is Magnetic Filtration? https://www.commercialfiltrationsupply.com/education/what-is-magnetic-filtration $\underline{. h t m l}$

[12] Eclipsemagnetics, Advanced Magnetic Filtration: Simple Operation with Outstand- 
ing Results (2018)

https://www.eclipsemagnetics.com/na/filtration-systems-how-it-works/

[13] Eclipse Magnetic Filtration Video (2014)

https://www.youtube.com/watch?v=ZsY0NW7PZZc

[14] Ghernaout, D., Ghernaout, B., Saiba, A., Boucherit, A. and Kellil, A. (2009) Removal of Humic Acids by Continuous Electromagnetic Treatment Followed by Electrocoagulation in Batch Using Aluminium Electrodes. Desalination, 239, 295-308. https://doi.org/10.1016/j.desal.2008.04.001

[15] Ghernaout, D., Mariche, A., Ghernaout, B. and Kellil, A. (2010) Electromagnetic Treatment-Bi-Electrocoagulation of Humic Acid in Continuous Mode Using Response Surface Method for Its Optimization and Application on Two Surface Waters. Desalination and Water Treatment, 22, 311-329. https://doi.org/10.5004/dwt.2010.1120

[16] Irki, S., Ghernaout, D. and Naceur, M.W. (2017) Decolourization of Methyl Orange (MO) by Electrocoagulation (EC) Using Iron Electrodes under a Magnetic Field (MF). Desalination and Water Treatment, 79, 368-377. https://doi.org/10.5004/dwt.2017.20797

[17] Ghernaout, D. (2018) Magnetic Field Generation in the Water Treatment Perspectives: An Overview. International Journal of Advanced and Applied Sciences, 5, 193-203. https://doi.org/10.21833/ijaas.2018.01.025

[18] Irki, S., Ghernaout, D., Naceur, M.W., Alghamdi, A. and Aichouni, M. (2018) Decolorization of Methyl Orange (MO) by Electrocoagulation (EC) Using Iron Electrodes under a Magnetic Field (MF). II. Effect of Connection Mode. World Journal of Applied Chemistry, 3, 56-64. https://doi.org/10.11648/j.wjac.20180302.13

[19] Chibowski, E. and Szcześ, A. (2018) Magnetic Water Treatment-A Review of the Latest Approaches. Chemosphere, 203, 54-67.

https://doi.org/10.1016/j.chemosphere.2018.03.160

[20] Coey, J.M.D. (2012) Magnetic Water Treatment-How Might It Work? Philosophical Magazine, 92, 3857-3865. https://doi.org/10.1080/14786435.2012.685968

[21] Simonič, M. and Urbancl, D. (2017) Alternating Magnetic Field Influence on Scaling in Pump Diffusers. Journal of Cleaner Production, 156, 445-450.

https://doi.org/10.1016/j.jclepro.2017.04.080

[22] Chang, M.-C. and Tai, C.Y. (2010) Effect of the Magnetic Field on the Growth Rate of Aragonite and the Precipitation of $\mathrm{CaCO}_{3}$. Chemical Engineering Journal, 164, 1-9. https://doi.org/10.1016/j.cej.2010.07.018

[23] Ghernaout, D. (2014) The Hydrophilic/Hydrophobic Ratio vs. Dissolved Organics Removal by Coagulation-A Review. Journal of King Saud University-Science, 26, 169-180. https://doi.org/10.1016/j.jksus.2013.09.005

[24] Ghernaout, D., Moulay, S., Ait Messaoudene, N., Aichouni, M., Naceur, M.W. and Boucherit, A. (2014) Coagulation and Chlorination of NOM and Algae in Water Treatment: A Review. International Journal of Environmental Monitoring and Analysis, 2, 23-34. https://doi.org/10.11648/j.ijema.s.2014020601.14

[25] Ghernaout, D., Al-Ghonamy, A.I., Boucherit, A., Ghernaout, B., Naceur, M.W., Ait Messaoudene, N., Aichouni, M., Mahjoubi, A.A. and Elboughdiri, N.A. (2015) Brownian Motion and Coagulation Process. American Journal of Environmental Protection, 4, 1-15. https://doi.org/10.11648/j.ajeps.s.2015040501.11

[26] Ghernaout, D. (2017) Entropy in the Brownian Motion (BM) and Coagulation Background. Colloid and Surface Science, 2, 143-161. 
[27] Saiba, A., Kourdali, S., Ghernaout, B. and Ghernaout, D. (2010) In Desalination, from 1987 to 2009, the Birth of a New Seawater Pretreatment Process: Electrocoagulation: An Overview. Desalination and Water Treatment, 16, 201-217. https://doi.org/10.5004/dwt.2010.1094

[28] Ghernaout, D. and Ghernaout, B. (2010) From Chemical Disinfection to Electrodisinfection: The Obligatory Itinerary? Desalination and Water Treatment, 16, 156-175. https://doi.org/10.5004/dwt.2010.1085

[29] Belhout, D., Ghernaout, D., Djezzar-Douakh, S. and Kellil, A. (2010) Electrocoagulation of a Raw Water of Ghrib Dam (Algeria) in Batch Using Iron Electrodes. Desalination and Water Treatment, 16, 1-9. https://doi.org/10.5004/dwt.2010.1081

[30] Ghernaout, B., Ghernaout, D. and Saiba, A. (2010) Algae and Cyanotoxins Removal by Coagulation/Flocculation: A Review. Desalination and Water Treatment, 20, 133-143. https://doi.org/10.5004/dwt.2010.1202

[31] Ghernaout, D., Naceur, M.W. and Aouabed, A. (2011) On the Dependence of Chlorine by-Products Generated Species Formation of the Electrode Material and Applied Charge during Electrochemical Water Treatment. Desalination, 270, 9-22. https://doi.org/10.1016/j.desal.2011.01.010

[32] Ghernaout, D. and Ghernaout, B. (2011) On the Controversial Effect of Sodium Sulphate as Supporting Electrolyte on Electrocoagulation Process: A Review. Desalination and Water Treatment, 27, 243-254. https://doi.org/10.5004/dwt.2011.1983

[33] Ghernaout, D. and Naceur, M.W. (2011) Ferrate(VI): In Situ Generation and Water Treatment-A Review. Desalination and Water Treatment, 30, 319-332. https://doi.org/10.5004/dwt.2011.2217

[34] Ghernaout, D., Naceur, M.W. and Ghernaout, B. (2011) A Review of Electrocoagulation as a Promising Coagulation Process for Improved Organic and Inorganic Matters Removal by Electrophoresis and Electroflotation. Desalination and Water Treatment, 28, 287-320. https://doi.org/10.5004/dwt.2011.1493

[35] Ghernaout, D., Irki, S. and Boucherit, A. (2014) Removal of $\mathrm{Cu}^{2+}$ and $\mathrm{Cd}^{2+}$, and Humic Acid and Phenol by Electrocoagulation Using Iron Electrodes. Desalination and Water Treatment, 52, 3256-3270. https://doi.org/10.1080/19443994.2013.852484

[36] Ghernaout, D., Al-Ghonamy, A.I., Naceur, M.W., Ait Messaoudene, N. and Aichouni, M. (2014) Influence of Operating Parameters on Electrocoagulation of C.I. Disperse Yellow 3. Journal of Electrochemical Science and Engineering, 4, 271-283. https://doi.org/10.5599/jese.2014.0065

[37] Ghernaout, D., Al-Ghonamy, A.I., Irki, S., Grini, A., Naceur, M.W., Ait Messaoudene, N. and Aichouni, M. (2014) Decolourization of Bromophenol Blue by Electrocoagulation Process. Trends in Chemical Engineering, 15, 29-39.

[38] Ghernaout, D., Benblidia, C. and Khemici, F. (2015) Microalgae Removal from Ghrib Dam (Ain Defla, Algeria) Water by Electroflotation Using Stainless Steel Electrodes. Desalination and Water Treatment, 54, 3328-3337.

https://doi.org/10.1080/19443994.2014.907749

[39] Ghernaout, D., Al-Ghonamy, A.I., Ait Messaoudene, N., Aichouni, M., Naceur, M.W., Benchelighem, F.Z. and Boucherit, A. (2015) Electrocoagulation of Direct Brown 2 (DB) and BF Cibacete Blue (CB) Using Aluminum Electrodes. Separation Science and Technology, 50, 1413-1420. https://doi.org/10.1080/01496395.2014.982763

[40] Ghernaout, D. (2017) Microorganisms' Electrochemical Disinfection Phenomena. EC Microbiology, 9, 160-169. 
[41] Ghernaout, D., Ghernaout, B. and Naceur, M.W. (2011) Embodying the Chemical Water Treatment in the Green Chemistry-A Review. Desalination, 271, 1-10. https://doi.org/10.1016/j.desal.2011.01.032

[42] Ghernaout, D. and Ghernaout, B. (2012) On the Concept of the Future Drinking Water Treatment Plant: Algae Harvesting from the Algal Biomass for Biodiesel Production-A Review. Desalination and Water Treatment, 49, 1-18. https://doi.org/10.1080/19443994.2012.708191

[43] Ghernaout, D. (2013) The Best Available Technology of Water/Wastewater Treatment and Seawater Desalination: Simulation of the Open Sky Seawater Distillation. Green and Sustainable Chemistry, 3, 68-88. https://doi.org/10.4236/gsc.2013.32012

[44] Seyfi, A., Afzalzadeh, R. and Hajnorouzi, A. (2017) Increase in Water Evaporation Rate with Increase in Static Magnetic Field Perpendicular to Water-Air Interface. Chemical Engineering and Processing-Process Intensification, 120, 195-200. https://doi.org/10.1016/j.cep.2017.06.009

[45] Ghernaout, D., Badis, A., Ghernaout, B. and Kellil, A. (2008) Application of Electrocoagulation in Escherichia coli Culture and Two Surface Waters. Desalination, 219, 118-125. https://doi.org/10.1016/j.desal.2007.05.010

[46] Ghernaout, D., Ghernaout, B. and Boucherit, A. (2008) Effect of pH on Electrocoagulation of Bentonite Suspensions in Batch Using Iron Electrodes. Journal of Dispersion Science and Technology, 29, 1272-1275. https://doi.org/10.1080/01932690701857483

[47] Ghernaout, D., Ghernaout, B. and Kellil, A. (2009) Natural Organic Matter Removal and Enhanced Coagulation as a Link between Coagulation and Electrocoagulation. Desalination and Water Treatment, 2, 203-222.

https://doi.org/10.5004/dwt.2009.116

[48] Ghernaout, D., Ghernaout, B., Boucherit, A., Naceur, M.W., Khelifa, A. and Kellil, A. (2009) Study on Mechanism of Electrocoagulation with Iron Electrodes in Idealised Conditions and Electrocoagulation of Humic Acids Solution in Batch Using Aluminium Electrodes. Desalination and Water Treatment, 8, 91-99. https://doi.org/10.5004/dwt.2009.668

[49] Ghernaout, D. and Ghernaout, B. (2012) Sweep Flocculation as a Second Form of Charge Neutralisation-A Review. Desalination and Water Treatment, 44, 15-28. https://doi.org/10.1080/19443994.2012.691699

[50] Ghernaout, D. (2013) Advanced Oxidation Phenomena in Electrocoagulation Process: A Myth or a Reality? Desalination and Water Treatment, 51, 7536-7554. https://doi.org/10.1080/19443994.2013.792520

[51] Ghernaout, D. (2019) Virus Removal by Electrocoagulation and Electrooxidation: New Findings and Future Trends. Journal of Environmental Science and Allied Research, 2019, 85-90.

[52] Ghernaout, D. (2019) Electrocoagulation Process for Microalgal Biotechnology-A Review. Applied Engineering, 3, 85-94.

[53] Han, X., Peng, Y. and Ma, Z. (2016) Effect of Magnetic Field on Optical Features of Water and $\mathrm{KCl}$ Solutions. Optik, 127, 6371-6376. https://doi.org/10.1016/j.ijleo.2016.04.096

[54] Lipus, L.C., Ačko, B. and Hamler, A. (2011) Electromagnets for High-Flow Water Processing. Chemical Engineering and Processing, 50, 952-958. https://doi.org/10.1016/j.cep.2011.07.004 